\title{
Proceeding
}

\section{Effect of theoretical biomechanics on open jump the platform jumps performance using jumps (vault) in artistic gymnastics}

\author{
HAIDER SAUD HASSAN ${ }^{1}$, SURA JAMIL HANNA², FERDOUS MAJEED AMEEN ${ }^{1}$ \\ ${ }^{1}$ College of Physical Education, University of Diyala \\ 2 College of Physical Education, University of Duhok
}

\begin{abstract}
Hassan, H., Hanna, S.J., \& Majeed Ameen, F. (2015). Effect of theoretical biomechanics on open jump the platform jumps performance using jumps (vault) in artistic gymnastics. J. Hum. Sport Exerc., 9(Proc2), pp.S742-S746. The biomechanics is an important science the physical education, thereby sports analyzed and thereafter correct the technical errors. Gymnastics is more related with biomechanics than other sports, this science contribute in the analysis, illustration, understanding, and improvement of sports technique. This study aimed to identify the effectiveness of theoretical information on the Platform Jumps (Vault) Performance, and to identify the difference of the performance level between pre-test and post-test. This research hypothesized significant differences in each of the theoretical biomechanics information in open jump on the platform jumps (Vault) performance between pre-test and post-test. An experiment used quasi experimental design, the population included 40 female undergraduate students in the physical education college, University of Diyala- Iraq during 2012-2013 divided into equal two groups. The biomechanics theoretical information that given to the students impacted on their skill and performance positively. Increase the level of Gymnastics performance of open jump on the platform for the female students. Key words: GYMNASTICS, BIOMECHANICS, JUMP.
\end{abstract}

Corresponding author. College of Physical Education, University of Diyala.

Asia Pacific Conference on Performance Analysis of Sport, 21-24 April 2014. Langkawi, Malaysia.

JOURNAL OF HUMAN SPORT \& EXERCISE ISSN 1988-5202

(c) Faculty of Education. University of Alicante

doi:10.14198/jhse.2015.10.Proc2.15 


\section{INTRODUCTION}

The biomechanics is an important science the physical education, thereby sports analyzed and thereafter correct the technical errors.

Gymnastics is more related with biomechanics than other sports, this science contribute in the analysis, illustration, understanding, and improvement of sports technique.

Biomechanics discover and identify the errors that we cannot found by visual observation and require camera or specific programs, this happen only by partition the skill and therefore decision the nature of each one (Brekea \& Yhyia, 2004).

The importance of this work is to identify the skills that depend on the biomechanics by justify and correct errors of the students and using video recorder of the skills.

Research problem included biomechanics science consideration a very hard course because it consist of physics, mathematic and analysis. Gymnastics is one of sports that interfere with complicated skills and difficult subjects especially when training students.

The Platform Jumps (Vault) Performance is a very special tool in gymnastics for recording the degree and type of skill and consider one of the perfect jump (Abd Al Wahab et al., 2010).

Depending on the researchers experience in teaching biomechanics and gymnastics, they try to find the impact of biomechanics and Gymnastics combination for best performance.

This study aimed to identify the effectiveness of theoretical information on the Platform Jumps (Vault) Performance, and to identify the difference of the performance level between pre-test and post-test.

This research hypothesized significant differences in each of the theoretical biomechanics information in open jump on the platform jumps (Vault) performance between pre-test and post-test.

\section{MATERIAL AND METHODS}

An experiment used quasi experimental design, the population included 40 female undergraduate students in the physical education college, University of Diyala- Iraq during 2012-2013 divided into equal two groups.

Statistically (Mean, Standard Division and T-test) used for current study, students performance evaluated using scale of (10) degree for Pre-test and post-test for the practical and theoretical test. The recorded video film was shown to a set of experts, the highest and lowest degree deleted and the mean of 2 middle degrees were computed for each student. The evaluation of the theoretical performance done by theoretical exam a 10 degree of biomechanics of open jump groundbreaking on platform (Fig.1). The exam papers divided into two groups experimental and control. 

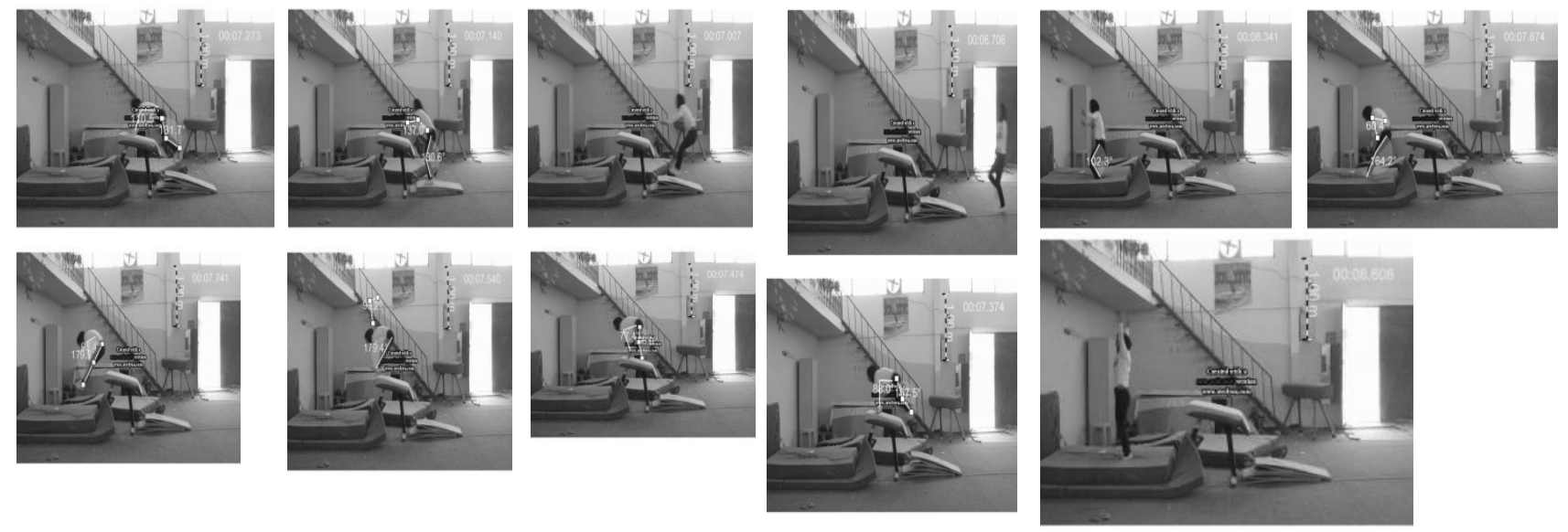

Figure 1. Open jump on the platform jumps (Vault) performance in artistic gymnastics

\section{RESULTS}

Data presented in Table 1 revealed significant differences in skill performance of the experimental and control group in pre and post tests for open jumping on a groundbreaking platform.

Table 1. Statistical parameters of experimental and control groups for both pre and post skill tests

\begin{tabular}{ccccccc}
\hline Groups & Tests & Mean & $\begin{array}{c}\text { Standard } \\
\text { Deviation }\end{array}$ & Calculated T & $\begin{array}{c}\text { Significance } \\
\text { level }\end{array}$ & Result \\
\hline Experimental & $\begin{array}{c}\text { Pre-test } \\
\text { Cont-test }\end{array}$ & 4.700 & 1.231 & 20.38 & 0.00 & Significant \\
& $\begin{array}{c}\text { Pre-test } \\
\text { Control }\end{array}$ & 2.35 & 0.81 & 12.93 & 0.00 & Significant \\
\hline
\end{tabular}

Table $\mathrm{t}=2.86$ at $\mathrm{D} . \mathrm{F}=19$ at $\leq 0.05$

The comparable differences in the mean between pre-test and post test for experimental and control group were $=(20.38)$ and $(12.93)$ according to T-test.

In theoretical test Table 2 considerable differences were resulted in the mean between pre-test and posttest for experimental and control group, since calculated test were $=(15.14)$ and (16.45).

Table 2. Theoretical test for experimental group and the control group in the pre-test and post-test

\begin{tabular}{ccccccc}
\hline Groups & Tests & Mean & $\begin{array}{c}\text { Standard } \\
\text { Deviation }\end{array}$ & Calculated T & $\begin{array}{c}\text { Significance } \\
\text { level }\end{array}$ & Result \\
\hline Experimental & $\begin{array}{c}\text { Pre-test } \\
\text { Post-test }\end{array}$ & 4.150 & 1.226 & 15.140 & 0.00 & Significant \\
& $\begin{array}{c}\text { Pre-test } \\
\text { Control }\end{array}$ & $\begin{array}{c}\text { Post-test } \\
\text { Po.900 }\end{array}$ & 0.788 & 16.457 & 0.00 & Significant \\
\hline
\end{tabular}

Table $\mathrm{t}=2.75$ at $\mathrm{D} . \mathrm{F}=38$ at $\leq 0.05$

Results of Table 3 proved non significant values between skill and theoretical in pre-test, whereas in posttest these skills were significant Table 4. 
Table 3. Differences in skill performance and the theoretical test for two groups of experimental and control in pre test

\begin{tabular}{|c|c|c|c|c|c|c|}
\hline Groups & Tests & Mean & $\begin{array}{l}\text { Standard } \\
\text { Deviation }\end{array}$ & Calculated T & $\begin{array}{c}\text { Significance } \\
\text { level }\end{array}$ & Result \\
\hline $\begin{array}{c}\text { Experimental } \\
\text { Control }\end{array}$ & Skill Test & $\begin{array}{l}3.350 \\
3.300\end{array}$ & $\begin{array}{l}0.988 \\
0.979\end{array}$ & 1.61 & 0.873 & $\begin{array}{c}\text { Non } \\
\text { Significant }\end{array}$ \\
\hline $\begin{array}{c}\text { Experimental } \\
\text { Control }\end{array}$ & $\begin{array}{c}\text { Theoretical } \\
\text { Test }\end{array}$ & $\begin{array}{l}3.900 \\
3.600\end{array}$ & $\begin{array}{l}1.119 \\
0.883\end{array}$ & 0.941 & 0.353 & $\begin{array}{c}\text { Non } \\
\text { Significant }\end{array}$ \\
\hline
\end{tabular}

Non- Significant differences in the mean between experimental and control group pre-test $=(0.161)$ measured by T-test.

Non Significant differences in the mean between Experimental and control group pre-test $=(0.941)$ measured by T-test.

Table 4. Differences in skill performance and the theoretical test for two groups of experimental and control in post- test

\begin{tabular}{ccccccc}
\hline Groups & Tests & Mean & $\begin{array}{c}\text { Standard } \\
\text { Deviation }\end{array}$ & Calculated T & $\begin{array}{c}\text { Significance } \\
\text { level }\end{array}$ & Result \\
\hline Experimental & Skill Test & 8.05 & 0.99 & 7.84 & 0.00 & Significant \\
$\quad$ Control & & 5.65 & 0.93 & & & \\
Experimental & Theoretical Test & 8.05 & 0.99 & 7.85 & 0.00 & Significant \\
Control & & 5.75 & 0.85 & &
\end{tabular}

There was a Significance differences in the mean between experimental and control group in post-test= (7.841) measured by T-test.

There is a Significance differences in the mean between experimental and control group in post-test= (7.852) measured by T-test.

\section{DISCUSSION}

Theoretical subject received by the respondents was more effective to obtain private information about the performance of technical skill required in jump groundbreaking Thus, the students responded the importance of joint angles occurring during the performance and the importance of power exerting at a short time and information of the center body mass during takeoff and touch the platform in addition to understanding the principles of second Newton laws.

Furthermore, results were clarified the importance of take hold the appropriate angles in the body joints at a moment of starting and aviation for retaining an inertial required to continued the state of body's kinetic or fixed that consider a scientific foundations should be associated with the process of learning and control equitably diagonals of the body for application the performance of this skill (Al Khalidy, 2010).

Positive development for the Experimental group on getting the theory information for biomechanics with practical practice for the Gymnastics skill of open jump on groundbreaking platform is bigger than control group. 


\section{CONCLUSIONS}

The biomechanics theoretical information that given to the students impacted on their skill and performance positively.

Increase the level of Gymnastics performance of open jump on the platform for the female students.

\section{RECOMMENDATIONS}

It is necessary to focus on the basic and principles of mechanical training in the educational curriculum according to the motor performance.

Confirmation the importance of photo to determination the mistakes of kinetic performance of artistic of gymnastics.

Teaching staff have to linking the artistic gymnastics and biomechanics science together with correct mechanical conditions that accompaniment the performance of artistic gymnastics.

\section{REFERENCES}

1. Mandalawi, Q.A. (1990). Tests and measurement in physical education. Mosul Press: Higher Education.

2. Al khalidy, M.J. (2010). Fundamentals of biomechanics. Iraq: Al Kofa University.

3. Brekea, M.J., \& Geda, M.Y. (2004). A correct way to catch by finger of pool hand of crossbow, Egypt: Eskendria University.

4. Abd Al Wahab, B., Esmaeel, E. \& Al Obadym, Y.N. (2010). Analysis of some variables of Biomechanics for performance and relationship with level of hard of the skills on the platform, al qadissiya magazine for the sciences of physical education.

5. Susan, J.H. (1995). Basic Biomechanics. USA: Mosbay. 